\title{
Intellectual capital and its impact on business performance: An empirical study of Portuguese hospitality and tourism sectors
}

\author{
Vânia Costa $^{1}(\mathbb{D})$, Lurdes Silva ${ }^{2}(\mathbb{D})$, Paula Loureiro ${ }^{2}$ (D) \\ ${ }^{1}$ School of Hospitality and Tourism, Polytechnic Institute of Cávado and Aveぬ CiTUR - Centro de Investigação, \\ Desenvolvimento e Inovaçãoem Turismo; GOVCOPP (Portugal) \\ ${ }^{2}$ School of Management, Polytechnic Institute of Cávado and Ave(Portugal) \\ vcosta@ipca.pt,lsilva@ipca.pt,ploureiro@ipca.pt
}

Received December, 2019

Accepted November, 2020

\section{Abstract}

Purpose: The propose of this study is to determine the influence of Intellectual Capital (IC) and its components' impact on Portuguese tourism organizations' business performance through Return on the assets (ROA). This work evaluates and compared the intellectual capital in its four dimensions: (i) capital employed; (ii) human capital; (iii) structural capital and (iv) relational capital.

Design/methodology: To approach the aim of the study the method Value Added Intellectual Coefficient (VAIC ${ }^{\mathrm{TM}}$ ) was applied and the practical data were collected from the Simplified Business Information (IES) through SABI (Iberian Balance Sheet Analysis System) database. The economic and financial information was collected from balance sheets and financial reports of 46.951 Portuguese companies in the hospitality and tourism sector during 2016. Multiple regression analysis was employed to identify the effect of IC components' that significantly contribute to the company performance.

Findings: The paper reveals that VAIC ${ }^{\mathrm{TM}}$, human capital efficiency coefficient (HCE), capital employed efficiency coefficient (CEE) and ROA are positively related among Portuguese's hospitality and tourism sector. However, the structural capital efficiency coefficient (SCE) presents a negative association with profitability and the results of the relationship between the variable relational efficiency coefficient (RCE) and ROA do not present statistical significance.

Practical implications: The application of the VAIC ${ }^{\mathrm{TM}}$ model presented in this paper provides a basis for practical application for management.

Originality/value: The paper represents a pioneering attempt to understand the relationship of intellectual capital and firm's profitability on Portuguese hospitality and tourism sector's, to provide solid recommendations for the importance of intellectual capital in the sustainable growth of organizations in this sector.

Keywords: Intellectual capital, VAIC ${ }^{\mathrm{TM}}$, Hospitality and tourism, Business performance

Jel Codes: G32, O34

\section{To cite this article:}

Costa, V., Silva, L., \& Loureiro, P. (2020). Intellectual capital and its impact on business performance: An empirical study of Portuguese hospitality and tourism sectors. Intangible Capital, 16(2), 78-89.

https://doi.org/10.3926/ic.1550 


\section{Introduction}

We live in a society where the need for differentiation and innovation is evident. In this society, the economy is based on knowledge. In view of the challenge of markets globalization, companies have intensified their concern for new advantages combined with knowledge-based resources such as know-how; innovation; the experience of employees; the quality of products and services; partnerships; the brands and the creativity. Thus, issues such as globalization and the evolution of information systems expose competition between organizations and intellectual capital is a resource that can make a difference. Intellectual capital is one of the subjects that have been recently tackled by different researchers for its importance to almost all organizations, industries and countries.

The measurement of knowledge is a relatively young discipline. In addition to intellectual capital measurement models (such as the Balanced Scorecard in Kaplan and Norton (1992); Skandia Navigator in Edvinsson (1997), there are also conceptualizations of intellectual capital accounting (Sabolovic, 2009). Pulic (1998, 2000, 2005), partially based on Skandia Navigator, developed a model of analysis the efficiency of intellectual capital that creates value, specifically the VAIC ${ }^{\mathrm{TM}}$ (Value Added Intellectual Coefficient), with the objective of offering a change in the perspective of business analysis. Using value added to measure performance, the Pulic model identifies both the size and efficiency of intellectual capital.

Most researchers studied the intellectual capital within different industries and sectors, but very few have studied intellectual capital in the context of the tourism industry (Sharabati, Radi, Nour, Durra \& Moghrabi, 2013). Tourism and travel is an important economic activity in most countries around the world, the sector generates nearly $10 \%$ of economic output and 313 million jobs, supports 1 in 10 jobs in the global economy or $9.9 \%$ of total employment in 2017 (United Nations World Tourism Organization, UNWTO, 2018).

Being an industry of people, it directly depends on the performance of activities, on skills, professionalism, quality and competitiveness. Therefore, it is essential to answer with precise planning politics, which should be the most approximated ones to the real needs of the sector. The tourism sector not only has an intensive need of labour force but also provides employment opportunity to a range of qualifications. Furthermore, (i) the social and technological developments experienced in the new economy, namely the information and communication technologies, (ii) the expansion of social networks, (iii) the impact of millennials in redefining business models, (iv) the higher level of information and demand of the consumers and the change of tourism needs, all these factors generated a set of opportunities and challenges that led to organizations seeking to new competitive advantages and to high levels of skills in the human capital (Kwon, 2009).

In this sense, this work contributed with a study for the tourism sector. Therefore, this research aims to investigate the effects of the intellectual capital on Portuguese hospitality and tourism sector's business performance, to provide solid recommendations for organizations, industries and decision makers concerned. Moreover, with our analysis we aim to answer our research question: "The Value Added Intellectual Coefficient and its components has a positive and significant association with the profitability of hospitality and tourism sector".

The remainder of the paper is organized as follows. Section 2 reviews the empirical research efforts in the literature. Section 3 describes the methodology, empirical models and hypothesis of the study. Section 4 presents the empirical results, specifically examine the impact of effective usage of IC on financial performance, analysing the relationship between IC and financial performance in the hospitality and tourism industry. Finally, section 4 presents the results of the research.

\section{Review of literature}

Intellectual capital has become a topic of great interest in the investigation. The new knowledge-based economy shifted attention to the intangible assets of organizations and how they are managed, being considered IC as valuable because the intangible assets are more important than tangible assets. So for organizations remain competitive should be performed a systematic approach of the IC assets.

Pulic (1998, 2000, 2003 and 2005) was one of the first authors that focused the research on the perspective of IC in order to explicitly focus on the relationship between IC and economic performance and the first that base 
their analyses only on the company's financial data. The VAIC ${ }^{\mathrm{TM}}$ method is used to calculate the rate of value added efficiency, based on the use of tangible and intangible assets of the company. This index is the sum of indicators: the efficient use of human capital, structural capital efficiency and effectiveness in the use of equity involvement in the creation of value-added.

For the design of the model VAIC ${ }^{\text {TM }}$, the author part of the goal to find a way of measuring the knowledgebased economy that is able to indicate the amount of value created and how productive is at all levels of business activity, business processes or into segments of society (Flores, García \& Adame, 2017). According to the authors, the main argument of Pulic (2008) draws on the knowledge of human resources that transform and incorporate knowledge into products and services that create value. In this sense, the author interprets the costs with knowledge workers as an investment in human capital, which expects a return.

There are several perspectives for evaluating a company's financial performance, which stresses that there is no unanimity regarding the indicators to be used. Empirical studies are usually based on the analysis of performance variables to measure company competitiveness. Studies of performance indicators are discussed in the literature and measured largely by the firm's financial outcomes.

Therefore, there is a large volume of published studies, which use profitability ratios as explanatory variables of the added value of intellectual capital in several sectors of activity. Table 1 below shows some of these studies.

\begin{tabular}{|c|c|c|}
\hline Autor & Purpose and methodology & Findings \\
\hline $\begin{array}{l}\text { Laing, Dunn and } \\
\text { Hughes-Lucas (2010) }\end{array}$ & $\begin{array}{l}\text { Examine the extent to which intellectual } \\
\text { capital (IC) adds value to a service provider } \\
\text { and presents an approach for interpreting the } \\
\text { results. } \\
\text { Pulic's VAIC }{ }^{\mathrm{TM}} \text { model }\end{array}$ & $\begin{array}{l}\text { The VAIC }{ }^{\mathrm{TM}} \text { model provides a robust tool for } \\
\text { assessing the efficient use of intellectual capital. } \\
\text { The model can be used by management to assess } \\
\text { their own organization's performance without } \\
\text { having to rely upon industry standards. }\end{array}$ \\
\hline Chan (2009) & $\begin{array}{l}\text { Investigate empirically if intellectual capital } \\
\text { has an impact on the financial aspects of } \\
\text { organizational performance. } \\
\text { Pulic's VAIC }{ }^{\mathrm{TM}} \text { model. }\end{array}$ & $\begin{array}{l}\text { The results of the analysis revealed no conclusive } \\
\text { evidence to support a definitive association } \\
\text { between IC and the four measures of financial } \\
\text { performance. }\end{array}$ \\
\hline $\begin{array}{l}\text { Ghosh and Mondal } \\
\text { (2009) }\end{array}$ & $\begin{array}{l}\text { Investigate the relationship between } \\
\text { performance of intellectual capital in a } \\
\text { company and three dimensions of corporate } \\
\text { financial performance. These three } \\
\text { dimensions are profitability, productivity and } \\
\text { market valuation. } \\
\text { Pulic's VAIC }\end{array}$ & $\begin{array}{l}\text { The analysis indicates that the relationships } \\
\text { between the performance of a company's } \\
\text { intellectual capital and conventional performance } \\
\text { indicators, namely, profitability, productivity and } \\
\text { market valuation, are varied. The findings suggest } \\
\text { that the VAIC }{ }^{\mathrm{TM}} \text { has significant positive } \\
\text { influence over profitability. }\end{array}$ \\
\hline $\begin{array}{l}\text { Muhammad and Ismail } \\
(2009)\end{array}$ & $\begin{array}{l}\text { This study therefore tries to investigate the } \\
\text { efficiency of intellectual capital and its } \\
\text { performance. }\end{array}$ & $\begin{array}{l}\text { It was found that the banking sector relied more } \\
\text { on intellectual capital followed by insurance } \\
\text { companies and Brokerage firms. The } \\
\text { relationships between Intellectual Capital } \\
\left(V^{\mathrm{V} A C^{\mathrm{TM}}} \text { ) had shown positive and significant }\right. \\
\text { relationships with both ROA and Profitability. }\end{array}$ \\
\hline Ting and Lean (2009) & $\begin{array}{l}\text { To examine the intellectual capital } \\
\text { performance and its relationship with } \\
\text { financial performance. } \\
\text { Pulic's VAIC }{ }^{\mathrm{TM}} \text { model. }\end{array}$ & $\begin{array}{l}\text { The paper reveals that VAIC }{ }^{\mathrm{TM}} \text { and ROA are } \\
\text { positively related. The results also show that the } \\
\text { three components of VAIC } \\
\text { with profitability. }\end{array}$ \\
\hline $\begin{array}{l}\text { Díez, Ochoa, Prieto and } \\
\text { Santidrián (2010) }\end{array}$ & $\begin{array}{l}\text { Value added intellectualcoefficient }\left(\mathrm{VAIC}^{\mathrm{TM}}\right) \\
\text { model. }\end{array}$ & $\begin{array}{l}\text { Despite having identified a relation between IC } \\
\text { and value creation, the study finds no evidence of } \\
\text { a significant relationship between the use of } \\
\text { human capital and structural capital indicators } \\
\text { and dependent variables other than sales growth, } \\
\text { such as return on assets (ROA) or productivity. }\end{array}$ \\
\hline
\end{tabular}




\begin{tabular}{|c|c|c|}
\hline Autor & Purpose and methodology & Findings \\
\hline Chang and Hsieh (2011) & $\begin{array}{l}\text { To examine the role of innovation capital in } \\
\text { the creation of value for business } \\
\text { organizations, namely on the companies' } \\
\text { operating, financial, and market performance. } \\
\text { A modified Value Added Intellectual } \\
\text { Coefficient }\left(\mathrm{VAIC}^{\mathrm{TM}}\right) \text { is used for analysis. } \\
\text { Pearson correlation and linear multiple } \\
\text { regression. }\end{array}$ & $\begin{array}{l}\text { IC in general has a negative impact on its } \\
\text { financial and market performance. However, the } \\
\text { association between innovation capital, which } \\
\text { captured by R\&D expenditure efficiency (RDE) } \\
\text { and companies' operating, financial and market } \\
\text { performance is significant. }\end{array}$ \\
\hline Sumedrea (2013) & $\begin{array}{l}\text { This paper analyses the structure of the } \\
\text { intellectual capital and its influence on the } \\
\text { economic performances. } \\
\text { VAIC }^{\mathrm{TM}_{\text {model. }}}\end{array}$ & $\begin{array}{l}\text { The results were obtained by applying certain } \\
\text { regression models and suggest that, in crisis time, } \\
\text { the human and the structural capital influence the } \\
\text { development of companies, while profitability is } \\
\text { additionally linked to the financial capital. ROE is } \\
\text { explained better by VAIC }\end{array}$ \\
\hline $\begin{array}{l}\text { Al-Musali and Ismail } \\
\text { (2014) }\end{array}$ & $\begin{array}{l}\text { Analyze intellectual capital performance and } \\
\text { investigates the impact of IC on financial } \\
\text { performance. } \\
\text { Pulic's VAIC }{ }^{\mathrm{TM}} \text { model. }\end{array}$ & $\begin{array}{l}\text { IC performance is low and it is positively } \\
\text { associated with bank financial performance } \\
\text { indicators. However, when VAIC }{ }^{\mathrm{TM}} \text { is split into } \\
\text { its components, the relationships between these } \\
\text { components and bank financial performance } \\
\text { indicators vary. }\end{array}$ \\
\hline $\begin{array}{l}\text { Matinfard and Khavari } \\
\text { (2015) }\end{array}$ & $\begin{array}{l}\text { Relationship between intellect capital } \\
\text { components and performance evaluation } \\
\text { indicators. } \\
\text { Pulic's VAICTM model }\end{array}$ & $\begin{array}{l}\text { The findings indicate a positive and significant } \\
\text { relationship between intellectual capital and } \\
\text { financial performance of companies. }\end{array}$ \\
\hline $\begin{array}{l}\text { Bontis, Janoševic and } \\
\text { Dženopoljac (2015) }\end{array}$ & $\begin{array}{l}\text { The purpose of this study is to examines to } \\
\text { what degree IC and its key components } \\
\text { affect the financial performance, including } \\
\text { operating profit, return on equity, return on } \\
\text { assets, profitability and employee } \\
\text { productivity. } \\
\text { Pulic's VAIC }\end{array}$ & $\begin{array}{l}\text { Results indicate that after controlling for firm size } \\
\text { and advantage, employee productivity and, to } \\
\text { some extent, profitability were affected by human } \\
\text { and structural capital. The research confirms that } \\
\text { the financial performance of hotels in Serbia } \\
\text { remains predominantly influenced by efficient use } \\
\text { of physical capital. }\end{array}$ \\
\hline $\begin{array}{l}\text { Hasan, Mohammadb } \\
\text { and Alamc (2017) }\end{array}$ & $\begin{array}{l}\text { To empirically investigate the relationship } \\
\text { between intellectual capital and financial } \\
\text { performance. } \\
\text { Pulic's VAIC }\end{array}$ & $\begin{array}{l}\text { VAIC }^{\mathrm{TM}} \text { and its components have a significant } \\
\text { association with profitability. }\end{array}$ \\
\hline $\begin{array}{l}\text { González, Calzada and } \\
\text { Hernández (2017) }\end{array}$ & $\begin{array}{l}\text { Identify intellectual capital as a key element } \\
\text { that contributes to competitiveness and } \\
\text { business success. } \\
\text { Pulic's VAIC } \\
\text { Correlation and its influence on factors such } \\
\text { as profitability, market capitalization and the } \\
\text { value of shares. }\end{array}$ & $\begin{array}{l}\text { It has been found that the } \\
\text { VAIC }^{\text {TM }} \text { and CEE, HCE and SCE positively } \\
\text { affect key elements: ROA, Market capitalization } \\
\text { MTB and at the level of the value of the stock. }\end{array}$ \\
\hline Kamath (2017) & $\begin{array}{l}\text { Investigate the impact of intellectual capital } \\
\text { (IC) efficiency on the financial and export } \\
\text { performance of firms in India. } \\
\text { Ante Pulic's value added intellectual } \\
\text { coefficient model in its modified version (M- } \\
\text { VAIC }^{\mathrm{TM}} \text { ) }\end{array}$ & $\begin{array}{l}\text { The results further confirmed that productivity } \\
\text { and export performance of all firms is highly } \\
\text { influenced by human capital efficiency. }\end{array}$ \\
\hline $\begin{array}{l}\text { Maji and Goswami } \\
\text { (2017) }\end{array}$ & $\begin{array}{l}\text { Modify Pulic's VAIC }{ }^{\mathrm{TM}} \text { model with the } \\
\text { primary intention of dealing with the } \\
\text { structural capital measurement deficiency. }\end{array}$ & $\begin{array}{l}\text { The results that both VAIC }{ }^{\mathrm{TM}} \text { and VAIC } \\
\text { advocate in favour of the positive influence of IC } \\
\text { and its components on firm performance. } \\
\text { It has been observed that both physical capital } \\
\text { and IC are crucial for enhancing firm value. }\end{array}$ \\
\hline
\end{tabular}




\begin{tabular}{|l|l|l|}
\hline \multicolumn{1}{|c|}{ Autor } & \multicolumn{1}{|c|}{ Purpose and methodology } & \multicolumn{1}{c|}{ Findings } \\
\hline Kayacan (2017) & $\begin{array}{l}\text { To analyze the relationship between the } \\
\text { intellectual capital performance and financial } \\
\text { performance. } \\
\text { Pulic's VAIC }\end{array}$ & $\begin{array}{l}\text { The intellectual capital performance of the } \\
\text { Turkish banking sector is generally affected by } \\
\text { human capital efficiency (HCE). Capital } \\
\text { employed efficiency (CEE) and human capital } \\
\text { efficiency (HCE) positively affect the financial } \\
\text { performance of banks. However, CEE has more } \\
\text { influence on the financial performance of banks } \\
\text { compared to HCE. }\end{array}$ \\
\hline $\begin{array}{l}\text { Farrukh and Joiya } \\
(2018)\end{array}$ & $\begin{array}{l}\text { Investigating the impact of intellectual } \\
\text { capital on the overall financial performance } \\
\text { and financial efficiency. } \\
\text { Pulic's VAIC } \\
\text { Panel data regression analysis. }\end{array}$ & $\begin{array}{l}\text { Exists the significant association between the } \\
\text { various components of Intellectual Capital and } \\
\text { the firm performance. }\end{array}$ \\
\hline $\begin{array}{l}\text { Khairiyansyah and } \\
\text { Vebtasvili (2018) } \\
\text { intellectual capital on profitability and } \\
\text { productivity. } \\
\text { It is an empirical study using PLS for the } \\
\text { data analysis. }\end{array}$ & $\begin{array}{l}\text { Research results show that intellectual capital has } \\
\text { a positive impact on ROA. The higher the value } \\
\text { of VAIC } \\
\text { banking company. This indicates that the } \\
\text { company is getting better in managing the assets } \\
\text { that result in the increased return on assets } \\
\text { owned companies measured by ROA. Companies } \\
\text { have been able to use the physical capital to } \\
\text { improve the efficiency of the company. }\end{array}$ \\
\hline
\end{tabular}

Table 1. Intellectual capital and profitability

After reviewing the literature of IC and the financial performance, we expect the relationship between IC and the financial performance of hospitality and tourism sector in Portugal.

\section{Methodology, empirical models and hypothesis}

\subsection{Methodology}

For research objectives align with the methodology, a quantitative study was conducts using secondary data. Data set in the present study analysis is based on secondary data in Portuguese hospitality and tourism industry, so was applied and the practical data were collected from the Simplified Business Information (IES) through SABI (Iberian Balance Sheet Analysis System) data base. Therefore, the economic and financial information was collected from balance sheets and financial reports of 46,951 Portuguese companies in the hospitality and tourism sector in 2016.

SPSS statistical software was used to conduct this analysis. To conclude the empirical analysis and the hypotheses, was performed an analysis using non-parametric tests since the sample has a large dimension. The analysis method against factual, used in this study, is known in the literature as have coarsened exact matching. According to Iacus, King and Porro (2012) is the direct comparison of the performance of groups of companies, which present similar characteristics to all the relevant variables. Translating, in targeting companies by groups, based on discrete observable variables and on comparative analysis of the evolution of average performance over a defined period, between enterprise groups.

VAIC $^{\mathrm{TM}}$ model aims to measure the efficiency and the creation of heat and, in this sense, evaluate the information concerning the efficiency of processes and people in the context of creating value by measuring the coefficients of efficiency in use of capital financial and intellectual capital (Martins, Morais \& Isidro, 2013). Specifically the measurement of intellectual capital is based on the relationship between these main components: (i) capital employed; (ii) human capital; (iii) structural capital and (iv)relational capital. The capital employed is based on the capital invested in the company, i.e. the accounting point of view reflects the net asset of the company. Human capital is translated by costs and finally structural capital arises as the value added obtained by the company from its inferred processes of human capital.

Pulic (2008) stresses the importance of increasing the level of efficiency of IC, considering that control of the creation of value is essential to take care of the efficiency of the resources used. Therefore, the author provides 
a way that allows an overview of productivity at all levels. The VAIC ${ }^{\mathrm{TM}}$ is a relational index at which the value added produced is compared to capital employed and to human capital, that is, the personal spending. VAIC ${ }^{\text {TM }}$ method calculates the overall efficiency of a company and their efficiency of IC.

Based on these definitions and assumptions, VAIC ${ }^{\mathrm{TM}}$ is calculated as the direct sum of the main indexes of efficiency, which are calculated as ratios of the human capital efficiency coefficient (HCE), the structural capital efficiency coefficient (SCE), relational efficiency coefficient (RCE) and the capital employed efficiency coefficient (CEE). The coefficient of the added value is given by the sum of the index of efficiency of IC and the efficiency index of physical and financial capital:

$$
\mathrm{VAIC}^{\mathrm{TM}}=\mathrm{ICE}+\mathrm{CEE}
$$

or

$$
\mathrm{VAIC}^{\mathrm{TM}}=\mathrm{HCE}+\mathrm{SCE}+\mathrm{RCE}+\mathrm{CEE}
$$

VAIC $^{\mathrm{TM}}$ and these components, HCE, SCE, RCE and CEE, are independent variables of this study.

Relative to the dependent variables profitability can be measured in a variety of ways. Prior studies have used Return on Asset (ROA) for measures of profitability (Chen, Cheng \& Hwang, 2005). Given the objective of the present investigation, two economic and financial indicators were selected, indicators that allow quantification of performance (Table 2).

\begin{tabular}{|l|l|l|}
\hline \multicolumn{1}{|c|}{ Ratio } & \multicolumn{1}{c|}{ Formula } & \multicolumn{1}{c|}{ Analysis } \\
\hline $\begin{array}{l}\text { ROA (Return on } \\
\text { Assets) }\end{array}$ & ROA $=\frac{\text { NetProfit }}{\text { TotalAssets }}$ & $\begin{array}{l}\text { ROA is the return of invested assets or profitability of assets, } \\
\text { reflects firms' efficiency in utilizing total assets, holding } \\
\text { constant firms' financing policy. }\end{array}$ \\
\hline
\end{tabular}

Table 2. Performance indicators (Adapted from Mladineo Susak, 2015; Constantin \& Loredana, 2012)

\subsection{Empirical models}

Following Pulic (2001), models of this study denote all of the given variables that may affect firm's performance.

$$
\begin{gathered}
\operatorname{ROA}_{\mathrm{it}}=\beta 0+\beta 1(\mathrm{CEE})_{\mathrm{it}}+\beta 2(\mathrm{HCE})_{\mathrm{it}}+\beta 3(\mathrm{SCE})_{\mathrm{it}}+\text { eit } \\
\operatorname{ROA}_{\mathrm{it}}=\beta 0+\beta 1(\mathrm{VAIC})_{\mathrm{it}}+\text { sit }
\end{gathered}
$$

Where, $\beta 0=$ Intercept and Coefficients of Slope or Slope of Line $\beta_{1}, \beta_{2}, \beta_{3}$, and $\varepsilon=$ Error Term.

\subsection{Hypothesis}

In this sense, and in order to measure the empirical impact of intellectual amount of capital on return on assets (ROA), the following hypotheses has been formulated:

Hypothesis 1 - Human capital efficiency (HCE) bas a positive and significant association with the Return on Assets (ROA) of hospitality and tourism sector.

Hypothesis 2 - Structural capital efficiency (SCE) bas a positive and significant association with the ROA of hospitality and tourism sector.

Hypothesis 3 - Relational capital efficiency (RCE) has a positive and significant association with the ROAof hospitality and tourism sector.

Hypothesis 4 - Capital employed efficiency (CEE) has a positive and significant association with the ROA of hospitality and tourism sector.

Hypothesis 5 - Value added intellectual coefficient (VAIC $\left.{ }^{T M}\right)$ has a positive and significant association with the ROA hospitality and of tourism sector. 


\section{Empirical results}

\subsection{Descriptive statistics}

Descriptive statistics of the study are present in the Table 3 . We will start by analyzing the VAIC ${ }^{\text {TM }}$ and its components as well as the ROA profitability indicators for descriptive statistics such as the mean, standard deviation and minimum and maximum values for $\mathrm{N}=46,951$ companies.

\begin{tabular}{|c|c|c|c|c|c|c|c|c|}
\hline & \multirow[t]{2}{*}{ Min } & \multirow[t]{2}{*}{ Max } & \multirow[t]{2}{*}{ Mean } & \multirow{2}{*}{$\begin{array}{c}\text { Std. } \\
\text { Deviation }\end{array}$} & \multicolumn{2}{|c|}{ Skewness } & \multicolumn{2}{|c|}{ Kurtosis } \\
\hline & & & & & Statistic & $\begin{array}{l}\text { Std. } \\
\text { Error }\end{array}$ & Statistic & $\begin{array}{l}\text { Std. } \\
\text { Error }\end{array}$ \\
\hline CEE & -106.27 & 98.53 & .5201 & 2.17033 & 2.027 & .012 & 711.643 & .025 \\
\hline HCE & -98.35 & 107.90 & 1.5607 & 6.56975 & 4.260 & .013 & 99.999 & .026 \\
\hline SCE & -1833.76 & 736.60 & .3342 & 16.89161 & -78.698 & .012 & 8026.497 & .025 \\
\hline RCE & -168.26 & 217.08 & .4681 & 5.75483 & 8.854 & .012 & 404.283 & .025 \\
\hline ICE & -98.52 & 108.89 & 1.9536 & 8.52301 & 2.393 & .013 & 53.173 & .026 \\
\hline VAIC $^{\text {TM }}$ & -99.96 & 125.84 & 3.0265 & 9.28434 & 2.043 & .013 & 44.281 & .026 \\
\hline ROA & -4401.78 & 380.32 & -.6133 & 23.37733 & -170.255 & .012 & 31811.935 & .025 \\
\hline
\end{tabular}

Table 3. Descriptive Statistics

The average values of the performance variables under study are -0.6133 for the ROA variable. Among the VAIC $^{\text {TM }}$ components, HCE has the highest mean value (mean=1.5607), indicating the creation of value through human capital of a company, i.e, the additional value created by a monetary unit spent per employee (such as Chan, 2009; Ting \& Lean, 2009; Chang \& Hsieh, 2011; Al-Musali \& Ismail, 2014; Matinfard \& Khavari, 2015; González, Calzada \& Hernández, 2017; Ozkan, Cakan \& Kayacan, 2017; Hasan et al., 2017; Maji \& Goswami, 2017; Farrukh \& Joiya, 2018). The average values of the SCE is low (about 0.3342). This indicator means that the higher the percentage of spending on personnel (HC) in value added (VA), the smaller the proportion of structural capital. In reality, the SCE measures how much capital a company can create through a monetary unit invested in aggregate value, that is, measures the productivity or efficiency of the added value. Standard deviation score is high in all components of the VAIC ${ }^{\mathrm{TM}}$ and mainly in the profitability variables, which indicates that the sample values show a high dispersion of profitability values in relation to the average, revealing great heterogeneity in these indicators among the entities analyzed.

The SCE, which presents lower mean and is the one that reveals greater standard deviation, revealing to be the element that, in addition to lower average is also the one that less homogeneity presents. These results in line with those of, namely, Farrukh and Joiya (2018).

After analyzing the descriptive statistics, we tested whether the data have a normal distribution to undertake correlation analysis. The results of the tests for normality show that analyzed variables have a normal distribution of data; therefore, Pearson correlation analysis was conducted to check for the existence of association between the variables.

The correlation analysis revealed several findings in terms of the relationship between the independent and dependent variables in the research model. The correlation results provided in Table 4 indicated statistically significant association among all variables except between SCE and HCE, RCE and HCE, ROA and ICE, ROA and RCE.

\begin{tabular}{|l|r|r|r|r|r|r|r|}
\cline { 2 - 9 } \multicolumn{1}{c|}{} & \multicolumn{1}{c|}{ CEE } & \multicolumn{1}{c|}{ HCE } & \multicolumn{1}{c|}{ SCE } & \multicolumn{1}{c|}{ ICE } & \multicolumn{1}{c|}{ RCE } & \multicolumn{1}{c|}{ VAIC } & \multicolumn{1}{c|}{ ROA } \\
\hline CEE & 1 & & & & & & \\
\hline HCE & $.040^{* *}$ & 1 & & & & & \\
\hline SCE & $-.054^{* *}$ & -.001 & 1 & & & & \\
\hline ICE & -.003 & $.770^{* *}$ & $.637^{* *}$ & 1 & & & \\
\hline RCE & $.019^{* *}$ & .009 & $-.205^{* *}$ & $-.197^{* *}$ & 1 & & \\
\hline VAIC & $.238^{* *}$ & $.722^{* *}$ & $.397^{* *}$ & $.810^{* *}$ & $.370^{* *}$ & & 1 \\
\hline ROA & $.325^{* *}$ & $.033^{* *}$ & $-.015^{* *}$ & -.003 & .005 & $.081^{* *}$ & \\
\hline
\end{tabular}

** $\operatorname{sig}<0.01 ; *$ sig $<0.05$

Table 4. Correlation Analysis among Variables 
As can be seen, the HCE presented with a high and statistically significant association with the ICE and with theVAIC ${ }^{\mathrm{TM}}$, revealing that human capital is the key element that contributes to the competitiveness and business success of the entities of this sector. Laing, Dunn and Hughes-Lucas (2010) consider that this may be interpreted as indicating a high reliance on human capital, which is consistent with the core business of being a hotel resort chain. However, it is clear that, although with a low association, it is the CEE is dominant in terms of value creation when ROA are used as indicators of created value (Chang \& Hsieh, 2011; Bontis, Janoševic \& Dženopoljac, 2015; Hasan et al, 2017).

The negative sign of correlation means a variation in the opposite direction in the variables. In this way, the component Structural Capital Efficiency (SCE) has a negative association on profitability indicators, revealing that the larger the structural capital of an entity, the lower its profitability, such as in the study of Chang and Hsieh (2011), Hasan et al. (2017) and Ozkan et al. (2017) and contrary to that verified by Farrukh and Joiya (2018).

Therefore, the results show that in Portugal the profitability of the tourism sector is more affected by the value of HCE rather than SCE and RCE (such as in the study of Al-Musali and Ismail (2014)). Physical and financial capital (capital employed efficiency coefficient -CEE), has a relatively low average as well as a low standard deviation when compared to the other indicators.

Correlation plays a strong influence in regression analysis, and the current results are expected to make its impact on the ROA model. None of the VAIC ${ }^{\text {TM }}$ components was found to have strong correlations with each other, proving that the model does not suffer for homogeneity issues.

\subsection{Regression analysis}

Table 5 summarizes the linear regression results for regression analysis. The result of the regression Model 1 of Return on asset (ROA) features as statistically significant variables to justify the variance of the ROA indicators such as CEE, HCE, RCE and SCE.

The CEE and HCE have a positive association with the ROA, and it is expected that the entities analyzed while have a high efficiency of physical and financial capital and high efficiency of human capital, have one too high profitability of the asset (as the result obtained by Díez, Ochoa, Prieto \& Santidrián, 2010). The capitalemployed efficiency (CEE) is what reveals greater relationships with company's ROA (as the result obtained by Muhammad \& Ismail, 2009).

These results lead to the confirmation of the first hypothesis that HCE has a positive and significant association with the firm performance (ROA) of hospitality and tourism sector and the Hypothesis 4: capital employed efficiency (CEE) is positively and significantly related to the firm performance (ROA) of hospitality and tourism sector.

On the other hand, the structural capital efficiency presents a negative association with profitability. These results are in line with those of the Bontis et al. (2015), in hotels of Serbia and are contrary to the hypothesis formulated in the structural capital efficiency (SCE) is positively and significantly related to the firm performance (ROA) of hospitality and tourism sector. The results related to the relational capital efficiency (RCE) variable are not statistically significant (Kamath, 2017), not confirming the Hypothesis 3.

\begin{tabular}{|l|r|r|}
\cline { 2 - 3 } \multicolumn{1}{c|}{} & \multicolumn{2}{c|}{ Dependent variables } \\
\cline { 2 - 3 } \multicolumn{1}{c|}{ Independent variables } & ROA & \multicolumn{2}{c|}{ t-Statistics } \\
\hline Model 1 & \multicolumn{2}{c|}{ Coefficients } \\
\hline Constant & -1.042 & $-32.638^{* *}$ \\
\hline CEE & 0.921 & $66.039^{* *}$ \\
\hline HCE & 0.021 & $4.709^{* *}$ \\
\hline SCE & -0.034 & $-6.363^{* *}$ \\
\hline RCE & -0.009 & -1.394 \\
\hline Adjusted R & & 0.115 \\
\hline F-value & & $1128,137^{* *}$ \\
\hline Prob>F & & 0.000 \\
\hline
\end{tabular}




\begin{tabular}{|c|c|c|}
\hline \multirow[b]{3}{*}{ Independent variables } & \multicolumn{2}{|c|}{ Dependent variables } \\
\hline & \multicolumn{2}{|c|}{ ROA } \\
\hline & Coefficients & t-Statistics \\
\hline \multicolumn{3}{|l|}{ Model 2} \\
\hline Constant & -0.617 & $-18.625^{* *}$ \\
\hline VAIC $^{\text {TM }}$ & 0.051 & $15.034 * *$ \\
\hline Adjusted $\mathrm{R}^{2}$ & & 0.006 \\
\hline F-value & & 226.017 \\
\hline Prob $>$ F & & $0.000^{* *}$ \\
\hline
\end{tabular}

$* *$ sig. $<.01$

Table 5. Regression Results

The VAIC ${ }^{\mathrm{TM}}$ indicator is also statistically significant to justify the ROA variance, proving the hypothesis 5 . This indicator is associated with high levels of added value of intellectual capital. The multiple regression models indicate the influence that VAIC ${ }^{\mathrm{TM}}$ have on the financial performance of companies (as the studies of Ghosh and Mondal (2009) in Indian software and pharmaceutical sector; Muhammad and Ismail (2009) in Malasian financial sector; Ting and Lean (2009) of financial institutions in Malaysia: Sumedrea (2013) in non-financial companies listed on Bucharest Stock Exchange; González et al. (2017) in the industrial sector of Mexico; Khairiyansyah and Vebtasvili (2018) in banking company listed on the Indonesia Stock Exchange; Farrukh and Joiya (2018) in various textile firms currently working in Pakistan).

However, a limitation of this model is presented with a low explanatory power of the variance of the profitability of the asset (about 11.5\%).

After taking into account results of statistical analysis, conclusions can be drawn regarding acceptance and rejection of hypothesis (Table 6).

\begin{tabular}{|c|c|c|}
\hline \multicolumn{2}{|r|}{ Hypothesis } & Acceptance/Rejection \\
\hline $\mathrm{H}_{1}$ & $\begin{array}{l}\text { HCE has a positive and significant association with ROA of hospitality and } \\
\text { tourism sector. }\end{array}$ & Accepted \\
\hline $\mathrm{H}_{2}$ & $\begin{array}{l}\text { SCE has a positive and significant association with ROA of hospitality and tourism } \\
\text { sector. }\end{array}$ & Rejected \\
\hline $\mathrm{H}_{3}$ & $\begin{array}{l}\text { RCE has a positive and significant association with ROA of hospitality and tourism } \\
\text { sector. }\end{array}$ & $\begin{array}{l}\text { No statistically significant } \\
\text { results }\end{array}$ \\
\hline $\mathrm{H}_{4}$ & $\begin{array}{l}\text { CEE has a positive and significant association with the ROA of hospitality and } \\
\text { tourism sector. }\end{array}$ & Accepted \\
\hline $\mathrm{H}_{5}$ & $\begin{array}{l}\mathrm{VAIC}^{\mathrm{TM}} \text { has a positive and significant association with the ROA of hospitality and } \\
\text { tourism sector. }\end{array}$ & Accepted \\
\hline
\end{tabular}

Table 6. Acceptance and rejection of hypothesis

Specifically, there is a significant and positive association between ROA and VAIC ${ }^{\mathrm{TM}}$, HCE and CEE.

\section{Discussions and conclusion}

The IC is recognized in the literature as the most important production factor in the current economy. There was a dramatic growth of intangible factors of development in the world in the last decades of the twentieth century, being responsible for this situation the large mergers and acquisitions, the expansion in the services sector, the sophistication of the technologies and markets and the strong customer orientation (Rodrigues, 2011).

According to economic theory, the tourist offer defines the destination or product, i.e. existence of added value for consumers of tourism product (Bunić \& Šušak, 2015). In this sense and given the importance of the tourism sector, the present research is focused on the VAIC ${ }^{\mathrm{TM}}$ model that has been used to examine the impact of effective usage of IC on financial performance, analysing the relationship between IC and financial performance in the hospitality and tourism industry. 
Findings of the study support the concept that intellectual capital has the potential to become the new source of wealth in the Portuguese hospitality and tourism sector's, and support that intellectual capital has a direct and positive effect on business performance.

After taking into account results of statistical analysis, conclusions can be drawn regarding acceptance and rejection of hypothesis. Specifically, there is a significant and positive association between ROA and VAIC ${ }^{\mathrm{TM}}$, HCE and CEE, accepting the Hypothesis 1, 4, 5. On the other hand, the structural capital efficiency (SCE) presents a negative association with profitability, rejecting the Hypothesis 2. Finally, the results of the relationship between the variable RCE and ROA do not present statistical significance, not confirming the Hypothesis 3.

However, it should be noted a limitation of this model considering is presented with a low explanatory power of the variance of the profitability of the asset (about 11.5\%). Future research on this subject should be undertaken, in particular can be done by testing with smaller samples, subdividing the sample by tourism subsectors and by different regions, analysing differences between these groups and including new control variables in order to increase the robustness of the model.

\section{Declaration of Conflicting Interests}

The authors declared no potential conflicts of interest with respect to the research, authorship, and/or publication of this article.

\section{Funding}

This work is financed by national funds through FCT - Fundação para a Ciência e a Tecnologia, I.P., under the scope of the project UID/BP/04470/2020.

\section{References}

Al-Musali, M., \& Ismail, K. (2014). Intellectual capital and its effect on financial performance of banks: Evidence from Saudi Arabia. International Conference on Accounting Studies, 18-19. https://doi.org/10.1016/j.sbspro.2014.11.068

Bontis, N., Janoševi, S., \& Dženopoljac, V. (2015). Intellectual capital in Serbia’s hotel industry. International Journal of Contemporary Hospitality Management, 27(6), 1365-1384. https://doi.org/10.1108/IJCHM-12-2013-0541

Bunić, J. \& Šušak, T. (2015). Financial Potential of Listed Tourism Companies in Republic of Croatia. Economy Transdisciplinarity Cognition, 18(1), 28-34.

Chan, H. (2009). Impact of intellectual capital on organizational performance: An empirical study of companies in the Hang Seng Index (Part I). The Learning Organization, 16(1), 4-21.

https://doi.org/10.1108/09696470910927641

Chang, W., \& Hsieh, J. (2011). Intellectual Capital and Value Creation- Is Innovation Capital a Missing Link?. International Journal of Business and Management, 6(2), 3-12. https://doi.org/10.5539/ijbm.v6n2p3

Chen, M.C., Cheng, S.J., \& Hwang, Y. (2005). An empirical investigation of the relationship between intellectual capital and firms' market value and financial performance. Journal of intellectual capital, 6(2), 159-176. https://doi.org/10.1108/14691930510592771

Constantin, C., \& Loredana, L.M. (2012). The Analysis of the Indicators Which Reflect the Ability of Companies of Facing Short Term Obligations and Medium and Long Term Maturities. Annals-Economy Series, 4, 89-95.

Díez, J., Ochoa, M., Prieto, M., \& Santidrián, A. (2010). Intellectual capital and value creation in Spanish firms. Journal of intellectual capital, 11(3), 348-367. https://doi.org/10.1108/14691931011064581

Edvinsson, L. (1997). Developing intellectual capital at Skandia. Long Range Planning, 30(3), 366-373.

Farrukh, W., \& Joiya, J. (2018). Impact of Intellectual Capital on Firm Performance. International Journal of Management and Economics Invention, 4(10), 1943-1952. 
Flores, M., García, M., \& Adame, M. (2017). Medición del capital intelectual en el sector bancario: Aplicación de los modelos Skandia y VAIC. Innovar, 27(66), 75-89. https://doi.org/10.15446/innovar.v27n66.66712

González, E., Calzada, M., \& Hernández, B. (2017). La medición del capital intelectual y su impacto en el rendimiento financiero en empresas del sector industrial en México. Contaduría y Administración, 62(1), 184-206. https://doi.org/10.1016/j.cya.2016.10.002

Ghosh, S., \& Mondal, A. (2009). Indian software and pharmaceutical sector IC and financial performance. Journal of Intellectual Capital, 10(3), 369-388.

Hasan, R., Mohammadb, N., \& Alamc, M.F. (2017). Impact of Intellectual Capital on Profitability - Conventional versus Islamic Banks. Journal of Accounting, Finance and Auditing Studies, 3/2, 64-80.

Iacus, S.M., King, G., \& Porro, G. (2012). Causal Inference Without Balance Checking: Coarsened Exact Matching. Political Analysis, 20(1), 1-24. https://doi.org/10.1093/pan/mpr013

Kamath, G.B. (2017). An investigation into intellectual capital efficiency and export performance of firms in India. Int. J. Learning and Intellectual Capital, 14(1), 47-75. https://doi.org/10.1504/IJLIC.2017.080641

Kaplan, R., \& Norton, D. (1992). The Balanced Scorecard - Measures that Drive Performance. Harvard Business Review, 70(1), 71-79.

Khairiyansyah, K., \& Vebtasvili, V. (2018). Relationship between Intellectual Capital with Profitability and Productivity in Indonesian Banking Industry. Jurnal Kenangan dan Perbankan, 22(1), 127-136. https://doi.org/10.26905/jkdp.v22i1.1577

Kwon, D.B. (2009). Human capital and its measurement. 3rd World forum on Statistics, Knowledge and Policy: Charting Progress Building Visions, Improving Live. Busan, Korea, October 27-30.

Laing, G., Dunn, J., \& Hughes-Lucas, S. (2010). Applying the VAIC ${ }^{\mathrm{TM}}$ model to Australian hotels. Journal of Intellectual Capital, 11(3), 269-283. https://doi.org/10.1108/14691931011064545

Maji, S., \& Goswami, M. (2017). Intellectual capital and firm performance in India: a comparative study between original and modified value added intellectual coefficient model. Int. J. Learning and Intellectual Capital, 14(1), 76-89. https://doi.org/10.1504/IJLIC.2017.080645

Martins, M.M., Morais, A. I., \& Isidro, H. (2013). The value of intellectual capital of the portuguese companies. Tourism \& Management Studies, 3, 848-862.

Matinfard, M., \& Khavari, A. (2015). The impact of intellectual capital on firm performance: Evidence from Tehran Stock Exchange. Management Science Letters, 5, 1005-1016. https://doi.org/10.5267/j.msl.2015.8.011

Mladineo, L., \& Susak, T. (2015). Value Added Tax Rate Change and Its Impact on Profitability. Economy Transdisciplinary Cognition, 18(1), 163.

Muhammad, N.M., \& Ismail, M.K. (2009). Intellectual Capital Efficiency and Firm's Performance: Study on Malaysian Financial Sectors. International Journal of Economics and Finance, 1(2), 206-212.

Ozkan, N., Cakan, S., \& Kayacan, M. (2017). Intellectual capital and financial performance: A study of the Turkish Banking Sector. Borsa Istanbul Review, 17(3), 190-198. https://doi.org/10.1016/j.bir.2016.03.001

Pulic, A. (1998). Measuring the Performance of Intellectual Potential in Knowledge Economy. 2nd McMaster World Congress. Austria: Austrian Team for Intellectual Potential.

Pulic, A. (2000). MVA and VAIC ${ }^{\text {TM }}$ Analysis of Randomly Selected Companies from FTSE 250, Austrian Intellectual Capital Research Center, Graz - London. Available online at: http://www.measuring-ip.at/Papers/ham99txt.htm

Pulic, A. (2003). Intellectual Capital - Does It Create or Destroy Value?. Submitted to PMA Intellectual Capital Symposium, Cranfield. https://doi.org/10.1108/13683040410524757 
Pulic, A. (2005). Value Creation Efficiency at National and Regional Levels: Case Study - CROAtia and The European Union. In A. Bounfour \& L. Edvinsson (Eds), Intellectual Capital for Communities. Oxford: Elsevier. https://doi.org/10.1016/B978-0-7506-7773-8.50015-7

Pulic, A. (2008). The principles of intellectual capital efficiency-A brief description. Croatian Intellectual Capital Center, Zagreb, 76.

Rodrigues, A.M. (2011). Activos intangíveis. Algumas reflexões contabilísticas e fiscais. In P. Otero, F. \& Araújo, J.T., Estudos em memória do Prof. Doutor J.L. Saldanha Sanches (pp. 469-520). Coimbra: Coimbra Editora, 4.

Sabolovic, M. (2009). Business Performance Analysis via VAICTM. European Research Studies, XII(3), 77-82. https://doi.org/10.35808/ersj/232

Sharabati, A-A, Radi, A-R, Nour, A-N, Durra, A-B., \& Moghrabi, K.M. (2013). The Effect of Intellectual Capital on Jordanian Tourism Sector's Business Performance. American Journal of Business and Management, 2(3), 210-221. https://doi.org: 10.11634/2167960613023

Sumedrea, S. (2013). Intellectual Capital and Firm Performance: A Dynamic Relationship in Crisis Time. Procedia Economics and Finance, 6, 137-144. https://doi.org/10.1016/S2212-5671(13)00125-1

Ting, I., \& Lean, H. (2009). Intellectual capital performance of financial institutions in Malaysia. Journal of Intellectual Capital, 10(4), 588-599. https://doi.org/10.1108/14691930910996661

United Nations World Tourism Organization [UNWTO] (2018). Travel \& Tourism Economic Impact 2018 World. London: United Nations World Tourism Organization. 